\title{
Beowulf and the intimacy of large parties
}

\author{
Roberta Frank
}

I like large parties. They're so intimate. At small parties there isn't any privacy.

\section{F. Scott Fitzgerald, The Great Gatsby ${ }^{1}$}

Intimacy sells. So, apparently, does Beowulf: feature films, a TV series, operas, graphic novels, translations, and a pride of companions attest to its allure. Everybody, it seems, wants to date the poem, including creationist tracts that read it as an eyewitness account of men cohabiting with dinosaurs. ${ }^{2}$ Beowulf is a flirt, alluring and ageless. Not even the time or place of its birth is entered on online sites: the less data, the more dates. The poem's seductive flash-forwards and strategic withdrawals, its pitiless channel shifting and intimations of strange doings down by the woodshed, tease and torment. Once hooked, admirers bemoan its 'lack of steady advance', ${ }^{3}$ disconcerting Sprünge (leaps) ${ }^{4}$ and Sprunghaftigkeit (erratic jumps), ${ }^{5}$ its abrupt hints, loose ends, and alarming lack of resolution. Its very coolness attracts. (Think Lola and Professor Rath in The Blue Angel.) Beowulf pulls hearers in a given direction, toys with them, makes them tingle with a sense of closeness, before showing them the door. There is an aching incompleteness to the poem's disclosures, a sense of something almost being said. And when something is only partially uncovered, as in a striptease, it awakens an urge to see more, to move from what is manifest to what is kept under wraps. Intimacy is a longing to connect with another, even with a poem.

The desire to meet is at the heart of all artfulness. Reading an old poem is like receiving a visitor from a distant land. You try to make sense of the stranger's words, the particular gestures and images of the text. The Wonders of the East in the Beowulf manuscript describes a polyglot race called the Donestre, who speak the languages of all peoples and use this skill to lure strangers to their death: 'When they encounter someone from a foreign country, they name 
him and his kinsmen with the names of acquaintances; and with false words they trick him and seize him, and after that eat all of him except for the head; and then they sit and weep over the head. ${ }^{6}$ Yes, small parties can go so, so wrong: guests trapped at table, immobilized, chewed over, seized upon by others as fresh meat. Films dine off this terror: Hannibal; The cook, the thief, his wife and her lover; The discreet charm of the bourgeoisie; A streetcar named Desire; Ang Lee's Eat, drink, man, woman; Vinterberg's The celebration; or any novel or play entitled The dinner or The dinner party. Avoid intimate literary soirées in particular.

Large parties, on the other hand, provide space for privacy, for bridging or at least minding the gap between bodies. At Gatsby's estate, individuals stroll, cocktails in hand, on spacious lawns crisscrossed by paths, 'through the sea-change of faces and voices and color under the constantly changing light, the swirls and eddies of strangers', meeting, separating, pausing, circling back, now moving rapidly, now at a crawl, introductions forgotten on the spot. Words waft in their wake - 'she persisted', 'butterfat', 'draining the fens', 'you don't say', 'toxic', 'recognize the ring?' 'plastics', 'believe me' - the rest muffled by the surf beating below. Imagination fills in the blanks. Eric Weiskott recently observed that much of the artistry of Old English poetry occurs in the spaces between half-lines. ${ }^{7}$ In the caesuras formed by the separate shards of stories in Beowulf, time itself sometimes seems to stutter, like a song on repeat. These ruptures and fissures in the narrative appear to offer points of access, a window on to some other temporality. But an entry to what? 'To things that disappeared and shouldn't have? To something grimly percolating offstage?

All forms of poetic recycling - borrowing, appropriation, referentiality - what Freud called Nachträglichkeit or 'retroactive meaningfulness' - are parasitic, dependent on the existence of a body of story that audiences were expected to know. Ovid counted on his audience's familiarity with Virgil's Dido to activate multiple layers of meaning in Heroides 7, and the Aeneid was never the same again. ${ }^{8}$ In Chaucer's Troilus and Criseyde, Pandarus, addressing a lovesick Troilus, quotes from a letter written by the Trojan shepherdess Oenone to Troilus's brother Paris (I, 652-5), after he had abandoned her for Greek Helen (Ovid's Heroides 5). James Simpson has noted the cunning with which Pandarus/Chaucer underlines the message's contemporaneity, saying to Troilus: 'You saw the letter that she wrote, I suppose?' (I, 656). ${ }^{9}$ A private letter by a heartbroken wife is viewed as public property, something possibly 
circulating at court and available to the recipient's brother. But Pandarus's reading is also drastically foreshortened. For in the same short letter, Oenone reports the prophecy of Cassandra, sister to Paris and Troilus, concerning the coming destruction of Troy. This is the violence and catastrophe, the legendary context, with which other poetic reimaginings of Oenone's lament powerfully end: with smoke, burning fire, and everywhere the sound of armed men. Yeats sets the scene in ten syllables: 'Hector is dead and there's a light in Troy' ('The Gyres'); in another poem, a cygnine god begets 'the broken wall, the burning roof and tower / And Agamemnon dead' ('Leda and the Swan'). Elizabeth Smart writes, 'Jupiter has been with Leda ... and now nothing can avert the Trojan War', confident that at least some of her readers will get the allusion to the engendering of Helen. ${ }^{10}$ Marlowe's 'topless towers of Ilion' are still burning in twenty-first-century North America. But Heorot? Hrothulf? Halga? What have Heoroweard or Heorogar to do with us? We have heard of Myrmidons and Priam, but not of Spear-Danes or Hrothgar. The sentence 'Halga has been with Yrsa ... and now nothing can avert the fall of the house of the Scyldings' no longer rings many bells.

\section{The back story}

Thence form your Judgement, thence your Notions bring,

And trace the Muses upward to their Spring.

Alexander Pope ${ }^{11}$

Beowulf opens ' $W e$ have heard of the glory of the kings of the Spear-Danes', followed by a snapshot of the dynasty's founder, one Scyld, tugging at mead-benches, disturbing furniture, grabbing shiny objects with his fists. The light will be brighter once he reaches the top. He begets an heir; then shoves off. That's life for you. Beowulf has one big back story - the fall of the dynasty of Danish kings founded by Scyld - almost none of which is told 'in' the poem. The first twenty-two hundred lines of Beowulf fill in the early moments of this history, introducing characters as they were before the turning points that led to tragedy. Beowulf, like Aeneas, is a new hero in legend-land, meeting in his travels famous figures whose careers were just taking off: here's Ingeld, not yet married; there's Hrothulf, silent as a log; and, look, Hrethric, a mere child. We are at the enfances stage of the Scylding century, a time not 
spoken of except in Beowulf. 'We have heard', says the narrator, and he means it: he is going to refashion an old story that everyone knows for his own purposes. He invites his audience to serve as his agile accomplices, his co-conspirators, in breaking and entering the past, to look on when, with a torturer's pity, he puts his characters through their pre-ordained paces. The legends themselves are present in the poem chiefly as mysterious dark matter, sensed by the shadows they cast and by their gravitational pull.

For over a century and a half, a distinguished tradition in Old English scholarship has traced correspondences between Beowulf and the stories of the Danish Scyldings as set out in dozens of later medieval Scandinavian and Icelandic texts. ${ }^{12}$ The same names, the same heroes, the same basic elements differently mixed and matched, appear again and again, trailing clouds of glory and a clod or two of less savoury matter as well. Beowulf features brief asides about three cousins: Hrethric, Hrothgar's son; Hrothulf (the North's Hrólfr Kraki), son of Hrothgar's younger brother; and Heoroweard, son of Hrothgar's older brother. In later legend, these three battle it out, with each done in by the next. But the Beowulf poet never mentions their conflicts, at least not directly. Hrothulf, who has been called 'the blankest' figure in the poem, will later become the greatest hero in the Scylding cycle. ${ }^{13}$ But why is the poet so reticent about his parentage? Forgetfulness? Ineptitude? Or a crime whose name cannot be spoken? Why does Wealhtheow so pointedly express confidence in his loyalty (1180-7) before turning towards her sons? If Denmark is really as chock-full of kindness and harmony as she says, why does she task Beowulf, an outsider, with looking after her boys (1228-31)? Beowulf, taking leave of Hrothgar, gravely offers his son a haven at his own court, should the young prince 'ever determine to visit' (1836-9). Why? Was cousin Hrothulf already flexing his muscles? And why for heaven's sake did Heoroweard's father not give him that ancestral mail-shirt (2155-62)? This piece of armour is made so conspicuously absent that the cause and result of its denial demand to be recalled.

Correspondences between allusions in Beowulf and the Danish/ Icelandic Scylding materials have haunted our handbooks since 1852. ${ }^{14}$ Three decades earlier, the scholar and poet N. F. S. Grundtvig recognized the Scyldings of Beowulf as the Skjöldung rulers of early Danish story, and their legends as behind the entire first part of the poem. ${ }^{15}$ It was another Dane, Ludvig Schrøder, who in 1875 first explicated certain scenes as foretelling the fall of the 
house of the Scyldings, the poem's dark backdrop. ${ }^{16}$ Subsequent discussions by Axel Olrik and R. W. Chambers deepened the links. By 1951 Dorothy Whitelock was able to conclude that key moments in Scylding history are so frequently foretold or foreseen in Beowulf

that it is obvious that the poet wishes them to be present in his hearers' thoughts as he tells his tale ... The poet describes how Hrothgar built a hall 'greater than the sons of men had ever heard of', and hints at its tragic end; he expects his audience to know that it was destined to see Hrothgar's strife with his own son-in-law, and at last to perish in flames in a war between kinfolk that put an end to the Scylding dynasty. ${ }^{17}$

Arthur Gilchrist Brodeur agreed:

Although the poet's allusions to the dynastic quarrels of the Shieldings (lines 1013-19; 1162b-68a; 1180b ff.; 1219-31) concern only Hrothulf's usurpation and the murder of Hrethric, he and his audience must have known of, and borne in mind, the later attack by Heoroweard (Hjörvarðr) on Hrothulf (Hrólf Kraki). ${ }^{18}$

Marijane Osborn stressed the precociousness of the Beowulf poet, whose information about the Scylding kings was far in advance of anyone writing in Scandinavia:

The Beowulf poet does not tell the full story of the Scylding dynasty; he merely alludes to that story, and he does so in a way suggesting his certainty that listeners can fill in the gaps. Today we can fill in those gaps only with reference to episodes of the story as they were told by later Scandinavian writers who probably knew nothing of Beowulf. ${ }^{19}$

James W. Earl detected a skeleton or two rattling in the Scylding family closet and surmised that the Old English poet suppressed stories involving rape or incest as too hot to handle, a kind of self-censorship. ${ }^{20}$ Or was the poet's deafening silence deployed to prick or excite his audience's recall, to turn absence into presence and thereby evoke the horror behind the curtain. To hear what is not being said in Beowulf involves tapping stories from a variety of late narratives, in full awareness that the conversation changes over the years, that each poet or saga-teller makes the story again in his own way. 


\section{Under the waterline}

What's past is prologue.

William Shakespeare, The Tempest ${ }^{21}$

Submerged narrative awakes, Kraken-like, in the opening lines of the poem. Beowulf has barely begun when we learn of the future destruction by fire of Heorot, Hrothgar's newly erected hall, and of in-law trouble waiting impatiently in the wings:

Sele hlifade
heah ond horngeap; heaðowylma bad,
laðan liges - ne wæs hit lenge pa gen
pæt se ecghete abumsweoran
æfter wælniðe wæcnan scolde. (81b-5)

(The hall towered, high and wide-gabled; it awaited deadly-surges, hostile flame - nor was it longer then yet that sword-hatred would awaken between son-in-law and father-in-law after deadly enmity.)

Allusions in Beowulf to Scylding dynastic history are set out concentrically, in a loose ring-structure, an enveloping barrow of remembrances. ${ }^{22}$ The first incident (the fire at Heorot, 81b-83a) links up with the last (resentful Heoroweard, 2155-62), the second (the in-law feud, 83b-85) with the penultimate (the Ingeld episode, 2020-69a), and the third (young Hrethric, 1180b-1191) with the antepenultimate (Beowulf's invitation, 1836-9). 'Two ominous tableaux - Hrothgar and Hrothulf at drink - occupy the middle panels (1014b-1019, 1162b-1165a). Their first tête-à-tête precedes the recital of the battle at Finnsburg, which introduces a sad queen, newly bereft of husband, brother, and son; the second follows that poetic entertainment, marking Wealhtheow's entrance and her Pollyannish 'no-problem-here-folks' speeches: 'I am certain Hrothulf will treat our heirs kindly since we were so good to him when he was a child' (1184-7). ${ }^{23}$ 'Be fitting in your deeds to my son, Beowulf. Here every comrade is true to the other, generous of heart, loyal to his lord; the troops are determined, the people all prepared; the rank-and-file, having drunk, do as I bid' (1226b-1231). Heartbreak will come. The queen puts a brave face on things, but history cannot be averted. The four quick references by the narrator to Danish story come before line 1169; the four incidents to which they correspond follow in reverse order and are spoken by characters in the poem who react to something they have seen or heard. The poet sets the table, then lets the help serve and clean up. 


\section{The outermost ring}

Time will say nothing but I told you so.

W. H. Auden ${ }^{24}$

The first indication that things will not end well for the Scyldings is the narrator's statement that Heorot is destined to go up in flames (81b-83a). The timing of this conflagration is left open, perhaps to accommodate different versions of the story in circulation. In Saxo's Gesta Danorum (ii.7.11-12), fire imagery illuminates Heoroweard's night attack on Hrothulf, whose last stand at the royal hall was widely celebrated in the poetry of the North. ${ }^{25}$ The Beowulf poet, in his final allusion to Scylding legend, dispatches Heoroweard in two and a half lines. Beowulf, presenting Hrothgar's gifts to Hygelac, announces that the Danish king wanted it known that the mail-coat in the collection was a royal heirloom, that before coming into Hrothgar's possession it had belonged to Heorogar, his older brother and predecessor on the throne. (Heorogar, the first son of Healfdene mentioned in the poem, will be the last.) For some unstated reason he refused to give the ancestral armour to his own (and loyal) son Heoroweard. As for Heoroweard, 'there he is', observes Marijane Osborn, 'in the shadows of the story, waiting for the twelfth-century Lejre Chronicle to develop him into a nemesis'. ${ }^{26}$ Before handing over this battle-gear to Hygelac, Beowulf recites its genealogy in a passage rich in alliteration and half-rhymes: ${ }^{27}$
Me ðis hildesceorp Hroðgar sealde
snotra fengel. Sume worde het
pæt ic his ærest ðe est gesægde.
Cwæð pæt hyt hæfde Hiorogar cyning
leod Scyldunga lange hwile.
No ðy ær suna sinum syllan wolde
hwatum Heorowearde peah he him hold wære
breostgewædu. Bruc ealles well. (2155-62)

(Hrothgar, the wise prince, gave me this battle-gear. He commanded that I should first tell you in certain words his good-will. He said that King Heorogar owned it, man of the Scyldings, for a long time. Not at all the sooner did he wish to give the breast-garment to his son, bold Heoroweard, although he was loyal to him. Enjoy all well.)

Why does the Beowulf poet mention Heoroweard at all? Was this prince initially passed over because he was too young? Why then didn't Hrothgar give him his father's armour when he came of age? He would have been a grown man by the time Beowulf arrived. 
And where was Heoroweard during Beowulf's visit? Abroad? Sulking in his tent? Was Hrothgar's gift to Hygelac meant to disinherit a nephew whose resentment at this slight eventually brought the glory of Heorot to an end? Causal connections are never made. Key moments in the fall of the Scyldings are hinted at - and then repressed. 'Enjoy all well', says Beowulf to Hygelac. The imperative singular of OE brucan, 'to enjoy, make use of', carries ominous overtones in Beowulf (the only poem in which the form occurs). OE bruc, 'enjoy', is otherwise spoken only by Wealhtheow, first when she hints to her husband that it may be time for him to do some estate planning (1177) and again when she presents Beowulf with a majestic neck-torque - after the narrator has reported its quick downward trajectory (1216). When a character in Beowulf says 'Enjoy', the wish seems seriously time-limited.

\section{The second ring}

A king is history's slave.

Leo Tolstoy ${ }^{28}$

The poet's second allusion to the Scylding story ( $83 \mathrm{~b}-85)$ concerns a son-in-law and father-in-law conflict. We later learn more about this feud and its chief protagonists, Ingeld and Hrothgar (2024-69a). ${ }^{29}$ On the basis of a piece of information picked up at the Danish court, Beowulf supplies Hygelac with an astute political forecast. Hrothgar has pledged his daughter to Ingeld, here prince of the Heathobards, in the hope of settling matters. Beowulf assesses the chances for success as nil: 'As a rule, the murderous spear will rest idle after the fall of a people only for a little while, even though the bride is good' (2029b-2031). Proverbs distance and depersonalize by appealing to an authority beyond the immediate moment, by splicing a particular situation into a universal pattern. Here Beowulf's sentence underlines the limited capacity of the Scyldings for action as they tread their predestined paths, fate once again stacking the odds against human aspirations. Hrothgar will not achieve peace by marrying off his daughter. Beowulf foresees the circumstances in which an unnamed old warrior (the famous Starkaðr/Starcatherus of later Scylding legend) might incite Ingeld's troops to vengeance. A plundered ancestral Heathobard sword spotted in the possession of a young Danish retainer will ensure that all bets are off:

Ponne bioð ( $\mathrm{a} b$ )rocene on ba healfe

aðsweord eorla; (syð)ðan Ingelde

weallað wælniðas, ond him wiflufan

æfter cearwælmum colran weorðað. (2063-6) 
(Then on both sides the oaths of men will be broken; then deadly hostility will boil up in Ingeld, and his love for the woman will become cooler after the seething of sorrow.)

The disaster predicted is expressed with restraint. The words walnid and ađsweord repeat and echo the very terms used by the poet in his opening allusion (83b-85). The precise details of this in-law feud remain elusive; the immediate outcome is distilled into a single comparative adjective: 'cooler'. Will Ingeld send his bride away? Kill her? Or will he just lose that special feeling? All semantic gradations from somewhat chilly to fatally cold are possible. Beowulf intimates without being specific, leaving much to an audience's memory and imagination. Hearers fill in according to taste and previous knowledge. Sound-effects reinforce the message. ${ }^{30}$ The half-lines 'weallað wælniðas' (lit. deadly-hates boil) and 'ond him wiflufan' (and his woman-loves), joined by alliteration, are divorced by internal half-rhymes (weal-/wael-vs. wif-/luf-), each member of the pair going its separate way. Images of heat and cold alliterate (doubly) across the caesura 'cearwælmum colran weorðað', the two half-lines linked firmly by resonant half-rhymes (cear-/weord-; -waelm/col-). Paronomasia binds the couplet (weall-, wael-, -walm) but not the couple: Beowulf's conjectures about the future of this marriage are acoustically buttressed. The feud will culminate with Ingeld's defeat at Heorot, famously referred to in the Old English poem Widsith.

\section{The inner circle}

Be afraid. Be very afraid.

The Fly ${ }^{31}$

The Beowulf poet counts on his hearers' intimacy with Scylding legend to 'get it' when he means more than he says. Sometimes ominous temporal adverbs or adverbial phrases ('at that time', 'then still', 'for a while') do the dirty work. At the celebration following Beowulf's victory over Grendel, the narrator twice zooms in on two men, Hrothgar and Hrothulf, uncle and nephew, sitting at the feast. Each tableau is a snapshot, a moment frozen in time, a minute caught and made to stand still. Would a contemporary audience, knowing what subsequently happened, have read the scene as we might a painting of Judith beguiling Holofernes or of Judas nodding 
at the Last Supper? 'The poet's description opens hopefully, but things quickly go downhill:

\author{
Heorot innan wæs \\ freondum afylled; nalles facenstafas \\ peod-Scyldingas penden fremedon. (1017b-1019)
}

(Heorot inside was filled with friends; at that time the Nation-Scyldings did not at all practise deceit.)

'Not at that time' does not reassure. As others have pointed out, the stressed and alliterating adverb penden seems to project the end of the very concord that the poet is advertising. The facenstafas, 'treachery, deceit' (ON feikenstafr, 'baleful rune') that the Scyldings did not then do does double duty as a magnetic 'ye olde' sign, pointing back and due north, to a far-off past and foreign place.

The same ambiguously joyous feast and the same two kinsmen soon stagger into view again. This time the narrator (in a metre that stands out from the surrounding lines) introduces a third man into the portrait:

Da cwom Wealhpeo forð

gan under gyldnum beage pær pa godan twegen sæton suhtergefæderan; pa gyt wæs hiera sib ætgædere, æghwylc oðrum trywe. Swylce pær Unferb pyle $æ$ fotum sæt frean Scyldinga; gehwylc hiora his ferhpe treowde, pæt he hæfde mod micel, peah pe he his magum nære arfæst æt ecga gelacum. (1162b-1168a)

(Then Wealhtheow came forward, walking under a golden torque to where the two good ones sat, nephew and paternal uncle; then yet was their friendship together, each true to the other. There, likewise, Unferth orator sat at the feet of the lord of the Scyldings; each of them trusted his mind, that he had great courage, though he had not been honourable to his kinsmen at swordplay.)

Then yet, still: for such little words to be effective, hearers would have had to be trained to respond to a storytelling technique so economical and so skilled in implication that the slightest hedge, the faintest trace of narrative smoke would set off an alarm. 'At that time their kinship bonds were still together'; a reminder that Scylding family feelings will soon sour, with the additional hint that Unferth, the overreaching press secretary with a worrisome record of fratricide, will have something to do with the break. This is a 
Houdini moment, a scene that has escaped by its own efforts from the confines of Scylding legend and now sits apart in deep silence. The passage above includes a long line ('sæton suhtergefæderan; pa gyt wæs hiera sib ætgædere') almost identical to one used by the Widsith poet of the same two individuals, as if lifted from or mimicking a phrase in a popular song or speech: ${ }^{32}$ 'Hrothulf and Hrothgar kept for the longest time kinship-ties together, nephew and paternal uncle [suhtorfadran], after they had driven off the kindred of Wicingas and humbled Ingeld's battle-line, cut down at Heorot the glory of the Heathobards.' English tradition seems to have bestowed on Hrothulf and Hrothgar a distinctive kinship epithet: suhtergefaderan, 'brother's son, father's brother', a rare dvandva- (or copulative) compound. In the surviving corpus, this epithet is restricted to these two heroes; it is their compound and no one else's, and may have advertised something specific (and possibly unspeakable) about their family relationship.

For if early skaldic verse is any model, Anglo-Saxon audiences were primed to locate narrative meaning in a poet's kinship epithets. In stanzas attributed to the Norse poet Bragi Boddason, the great Ermanaric, king of the Goths, is designated by the epithet 'Randver's chief-kinsman', naming the son (Randvér) he recently let swing on the gallows; the skald also refers to the Gothic king as 'Joy of Bird-Hildr [= Svanhildr]', an epithet evoking the young wife he cruelly slew at the same time. Another kinship compound, 'Erpr's bosom-brothers', identifies the avenging heroes of the tale, but solely through the sibling they had wrongheadedly killed. ${ }^{33}$ Pointed circumlocutions like these open cracks in the frame surrounding the immediate action of the story, letting past and future in; they are condensed allusions to a legend everyone knew. Taken innocently, the epithet suhtergefederan, 'brother's son, father's brother', describes an everyday kinship relation; read suspiciously, it is a mocking reminder of a particular family's disintegration.

When a few lines later Wealhtheow anxiously insists that Hrothulf will repay her and Hrothgar for their kindnesses to him when he was a child (using another antique-looking compound), that he will be good to their boys when her aged husband departs this life (1180-7), the poet is presumably counting on his audience to recall that Hrothulf did not play 'nice-nice' with his cousins before taking the throne. The narrator allows a quick glimpse of the two boys, Hrethric and Hrothmund, Beowulf by their side. Hrothmund at once vanishes from the poem, but Hrethric is mentioned one more time, in Beowulf's farewell to Hrothgar (1817-39). After pledging 
military support should the Danish king ever need it, Beowulf adds a further sweetener:

Gif him ponne Hrepric to hofum Geata gepingeð peodnes bearn, he mæg pær fela freonda findan; feorcypðe beoð selran gesohte pæm pe him selfa deah. (1836-9)

(If then Hrethric, child of the ruler, determines to go to the court of the Geats, he will be able to find many friends there; far nations are better visited by one excellent in himself.)

Conceivably (given the likelihood of problems with Hrethric's succession) Beowulf is not offering the lad a junior year abroad, but a political safe haven. The generalizing proverb that follows is a polite compliment to both the prince and his father. Hrothgar immediately recognizes Beowulf's diplomatic tact and praises his indirection ('I have never heard anyone at such a young age make arrangements more wisely', 1842b-1843). The Danish king has no trouble translating the speaker's round-aboutness, his excruciatingly good manners. Here, as elsewhere in Beowulf, strength of feeling is conveyed by not being spoken. Intimacy is the thing with feathers that makes your interlocutor either respond quickly with an appreciative 'I get it; I know just what you mean', or send you to a specialist.

\section{Surfacing}

The famous

Northern reticence, the tight gag of place And times

\section{Seamus Heaney ${ }^{34}$}

The secret to success in almost any relationship is knowing what not to say. Talking to anyone not yourself is always problematic; but, then, so is talking to yourself. There may be questions too cutting, direct, or trivial to ask our poem, especially when its characters sound perceptually challenged. We must show tender solicitude for the tiniest hints and fragments of its vanished past, the preceding and surrounding world that gave context to the poem's utterances. So what if there are things about Beowulf we shall never fully understand. Every communication is faulty, every comparison lame, every interpretation imperfect.

A shared sense of wit or style is often the spark for an intimate relationship. The Beowulf poet entices with his wryness and 
obliqueness, turning hearers into accomplices, companions in making meaning, if not whoopee: 'Cain did not rejoice in that crime' (= God sent him packing) (109); Grendel 'mourned not at all for his crimes' (= he was a happy camper) (136-7); 'he didn't want to sue for peace or pay wergild' (= some men prefer to eat and run) (154-8); 'nor did his death seem painful to them' (= it was party-time at Heorot) (841-2). The poem employs almost a hundred of these negations, along with a troop of adverbial down-toners: 'not much' or 'little' (= not at all), 'not many' (= none), 'not least' (= greatest), 'enough' (= many), 'seldom' (= never), 'long' (= forever), and 'often' (= always). ${ }^{35}$ The hero early confides about his heroism: 'I don't brag about it much' (586). (Imagine dating someone who talks like this.) There is an inherent fuzziness or imprecision in such evaluations, foreshadowing the basic fact of modern physics that 'nothing can ever be measured with perfect accuracy'. ${ }^{36}$ Peter Ackroyd, searching in Anglo-Saxon England for the origins of the English imagination, speaks of a common 'fierce reticence', a 'brevity of understatement, fading into silence'. 'Instead of asking what is "modern" about the Anglo-Saxons', he urges, 'inquire instead what is Anglo-Saxon about "the modern". ${ }^{37}$ Think of Edward Gibbon confiding in a footnote: 'The portrait of Athanasius is one of the passages of my history with which I am the least dissatisfied.'

\section{Only connect}

For every image of the past that is not recognized by the present as one of its own concerns threatens to disappear irretrievably.

Walter Benjamin ${ }^{38}$

History matters in Beowulf. Old Hrothgar urges Beowulf to learn from the example of Heremod, a pre-Scylding king who became pathologically greedy and violent, and had to be removed: ${ }^{39}$

Breat bolgen-mod beod-geneatas, eaxl-gesteallan, op pæt he ana hwearf, mære beoden mon-dreamum from.

Đeah pe hine mihtig God mægenes wynnum, eafepum stepte ofer ealle men, forð gefremede, hwæpere him on ferhpe greow breost-hord blod-reow, nallas beagas geaf

Denum æfter dome; dreamleas gebad pæt he pæs gewinnes weorc prowade, leod-bealo longsum. (1713-22a) 
(Enraged, he cut down his table-companions, his intimate comrades, until that famous prince turned away alone from human pleasures. Although mighty God exalted him in the joys of power and strength, advanced him over all men, nevertheless a bloodthirsty breast-hoard grew in his mind; not at all did he give rings to the Danes for their glory; he endured, joyless, to suffer the pain of that struggle, a longlasting evil to his people.)

Hrothgar's lesson in leadership suggests that the poem, when new, had something to say to its contemporaries. But what can it tell us? In a moving essay, Gillian R. Overing cites the comment in the latest edition of Klaeber's work that 'perhaps the most important audience of all is the implied (or fictional) audience that is generated by the rhetorical action of the text itself with each and every reading of it'. ${ }^{40}$ What can be said about Beowulf as a poem for our time? What does it say to and for our 'now'? How does the poem's history meet ours? Is intimacy with Beowulf desirable or even possible? For the poem refuses to stay put.

Beowulf in its early eleventh-century manuscript is already in transition, a poem making a progress through time. Oddly named strangers move through the work at different speeds, on different trajectories, some up, some down, all under a darkening sky. Stories arrive and depart with the suddenness of a summer cloudburst. Night-inhabiting fen creatures (the past in drag) mock human aspirations. A dragon rejoices in his wall. Nicholas Howe early stressed the need to 'recognize the subtle and inescapable interactions between the historical moment at which one writes as a critic and the historical moment about which one writes'. ${ }^{41}$ The joy of communal celebration in Beowulf is shadowed, front and back, by images of loss and suffering. The poem concludes with an image of the hero's gold-rich barrow standing high and broad on its headland, a guide to sailors of the future. Earlier we were presented with another powerful image, of a woman fleeing war and enslavement, stripped of gold adornments and sick at heart, 'treading foreign paths, not once but often' (3019). No one promised that intimacy with Beowulf would be easy.

The large parties of Beowulf - the three monstrous beings at the heart of the poem - publicly got their due in J. R. R. Tolkien's influential lecture of $1936 .{ }^{42}$ This Oxford don had learned Old English early, read the poem at a young age with schoolmates, and never lost his fondness for golden treasure and coiled dragons. Some time after 1920 he began a translation of Beowulf, finishing it in 1926 before putting it aside (and then fiddling with it for decades). 
The translation and commentary were published in 2014 by his son, Christopher. ${ }^{43}$ Why, wondered reviewers, had Tolkien not published his 'Beowulf' himself? Joan Acocella in The New Yorker imagined that he didn't do so because the poem meant so much to him; it was his lodestar, his muse, and the thought of exposing it dressed by him to all comers was disquieting: 'Perhaps, in the dark of night, he already knew what would happen: that he would never publish his beautiful "Beowulf," and that his intimacy with the poem, more beautiful, would remain between him and the poet - a secret love. ${ }^{44}$ It is not difficult to date Beowulf. It has shown itself liberal and generous, some might even say promiscuous, in its attachments. But to have, like Tolkien, a deep, life-long relationship with the poem and want never to let it go - this is a bonding rare and, because inevitably one-sided, strangely moving.

\section{Notes}

1 F. Scott Fitzgerald, The Great Gatsby (New York: Scribner, 1925), p. 49.

2 See, for example, Bill Cooper, After the Flood: the early post-Flood history of Europe traced back to Noah (Chichester: New Wine Press, 1993). Grendel is already a Tyrannosaurus Rex in 'Beowulf the Mighty', a 1955 one-shot from Eastern Color comic artist Bill Ely.

3 See R. D. Fulk, Robert E. Bjork, and John D. Niles (eds), Klaeber's Beowulf and the fight at Finnsburg, corrected reprint of 4th edn (Toronto: University of Toronto Press, 2009), p. xcv. Citations are from this edition; all translations are mine. Frederick Klaeber famously used 'Lack of steady advance' as a subtitle (3rd edn, Boston: D. C. Heath and Co., 1950), p. lvii. In 1871 Lewis Carroll in Through the looking glass had introduced an Anglo-Saxon messenger whose similar way of progressing down a road - forward, twist, pause, leap - drew Alice's attention.

4 Franz Joseph Mone, 'Zur Kritik des Gedichts vom Beowulf', in Untersuchungen zur Geschichte der teutschen Heldensage, vol. 1 of 2nd series of the Bibliothek der gesammten deutschen national-literatur (Quedlinburg and Leipzig, 1836), pp. 129-36, at 130.

5 Alois Brandl, 'Die angelsächsische Literatur', Grundriss der germanischen Philologie, ed. Hermann Paul, 2nd edn (Strassburg, 1901-09), vol. 2, pt A, pp. 941-1134, at 1005. Issued separately with the same pagination: Geschichte der angelsächsische Literatur (Strassburg, 1908).

6 The wonders of the East, no. 20: 'Ponne hy fremdes cynnes mannan geseoð, bonne nemnað hy hyne ond his magas cupra manna naman, ond mid leaslicum wordum hy hine beswicað ond hine gefoð, ond æfter 
pan hy hine fretað ealne buton pon heafde ond ponne sittað ond wepað ofer pam heafde.' For Latin and Old English texts and translation, see Andy Orchard, Pride and prodigies: studies in the monsters of the Beowulfmanuscript (Cambridge: D. S. Brewer, 1995), pp. 175-203, at 196-7; also R. D. Fulk (ed. and trans.), The 'Beowulf' manuscript: complete texts and the fight at Finnsburg, Dumbarton Oaks Medieval Library, 3 (Cambridge, MA: Harvard University Press, 2010), pp. 16-31, at 24-5.

7 Eric Weiskott, 'Old English poetry, verse by verse', ASE, 44 (2015), 95-130, at 113 .

8 See Marilyn Desmond, Reading Dido: gender, textuality, and the medieval 'Aeneid' (Minneapolis, MN: University of Minnesota Press, 1994), p. 34.

9 James Simpson, 'Chaucer as a European writer', in Seth Lerer (ed.), The Yale companion to Chaucer (New Haven, CT: Yale University Press, 2006), pp. 55-86, at 63.

10 Elizabeth Smart, By Grand Central Station I sat down and wept (London: Nicholson and Watson, 1945), pp. 28-9.

11 Alexander Pope, An essay on criticism (London, 1711), p. 10.

12 The standard discussion of Scylding analogues is Axel Olrik, Danmarks heltedigtning: en oldtidsstudie. Vol. 1. Rolf Krake og den celdre Skjoldungrakke (Copenhagen: G.E.C. Gad, 1903); translated in Axel Olrik, The heroic legends of Denmark, trans. Lee M. Hollander (New York: The American-Scandinavian Foundation, Oxford University Press, 1919; repr. New York: Kraus, 1971). Also R. W. Chambers, Beowulf: an introduction to the study of the poem with a discussion of the stories of Offa and Finn, 3rd edn, with a supplement by C. L. Wrenn (Cambridge: Cambridge University Press, 1959). See, too, Walter A. Berendsohn, Zur vorgeschichte des Beowulf (Copenhagen: Levin and Munksgaard, 1935) and Frederick Klaeber's editions of the poem (1922-55). Convenient translations of the Scylding material can be found in G. N. Garmonsway and Jacqueline Simpson, Beowulf and its analogues (New York: Dutton, 1968); in Fulk, Bjork, and Niles (eds), Klaeber's Beowulf, pp. 291-315; and in John D. Niles and Marijane Osborn, Beowulf and Lejre (Tempe, AZ: ACMRS, 2007), pp. 297-387.

13 Andy Orchard, A critical companion to Beowulf (Cambridge: D. S. Brewer, 2003), p. 245; Thomas A. Shippey, Beowulf (London: Edward Arnold, 1978), p. 32.

14 Gísli Brynjúlfsson, 'Oldengelsk og oldnordisk', Antikvarisk tidskrift för Sverige, 4 (1852-54), 81-143, at 130; cited by Theodore M. Andersson, 'Sources and analogues', in Robert E. Bjork and John D. Niles (eds), A Beowulf handbook (Lincoln, NE: University of Nebraska Press, 1997), pp. $125-48$, at 130 .

15 N. F. S. Grundtvig, 'Et par ord om det nys udkomme angelsaeksiske Digt', Nyeste Skilderie af Kjøbenhavn, 60 (1815), cols. 945-52; Thomas A. Shippey and Andreas Haarder, Beowulf: the critical heritage (New 
York: Routledge, 1998), pp. 108-13; Marijane Osborn, 'The Lejre connection in Beowulf scholarship', in Niles and Osborn, Beowulf and Lejre, pp. 287-93, at 287-8.

16 Ludvig Schrøder, Om Bjovulfs-drapen: efter en rakke foredrag på folkehöjskolen i Askov (Copenhagen: Karl Schønberg, 1875).

17 Dorothy Whitelock, The audience of Beowulf (Oxford: Clarendon Press, 1951), pp. 34-5; reprinted with same pagination in Dorothy Whitelock, From Bede to Alfred: studies in early Anglo-Saxon literature and history (London: Variorum Reprints, 1980).

18 Arthur Gilchrist Brodeur, The art of Beowulf (Berkeley, CA: University of California Press, 1959), p. 77, n. 5.

19 Marijane Osborn, 'Legends of Lejre, home of kings', in Niles and Osborn, Beowulf and Lejre, pp. 235-54, at 235.

20 James W. Earl, 'The forbidden Beowulf: haunted by incest', PMLA, 125 (2010), 289-305.

21 William Shakespeare, The Tempest (London, 1611), Act II, scene i.

22 On ring composition and other mnemotechnic designs in Old English verse, see Adeline Courtney Bartlett, The larger rhetorical patterns in Anglo-Saxon poetry (New York: Columbia University Press, 1935), pp. 9-29; Constance B. Hieatt, 'Envelope patterns and the structure of Beowulf', English studies in Canada, 1 (1975), 249-65; H. Ward Tonfeldt, 'Ring structure in Beowulf', Neophilologus, 61 (1977), 443-62; and John D. Niles, Beowulf: the poem and its tradition (Cambridge, MA: Harvard University Press, 1983), pp. 152-62.

23 The word used here for 'child' (umbor) occurs three times in Old English, twice in Beowulf as part of the probable compound umborwesende, 'being a child' (46b, 1187a). Its etymology is uncertain: it has been linked to both Gothic wamba, 'womb', and Latin umbo, 'boss' (of a shield) as well as 'navel'. ('Child', a word peculiar to English, may be related to Gothic kilpei, another word for 'womb'.) See Hans Schabram, 'Bemerkungen zur etymologie von ae. umbor "kind", in Florilegium linguisticum: Festschrift für Wolfgang P. Schmid zum 70. geburtstag, ed. Eckhardt Eggers et al. (Frankfurt: Lang, 1990), pp. 403-14.

24 W. H. Auden, 'If I could tell you', in Collected shorter poems 1927-1957 (New York: Random House, 1967), p. 201.

25 Many commentators take these lines to allude to the Heathobard feud, either Ingeld's assault on Heorot or, in the previous generation, his father's. Chambers, in his revision of A. J. Wyatt's edition (Beowulf with the Finnsburg Fragment [Cambridge: Cambridge University Press, 1914], note to lines 82-5), took lines $82 \mathrm{~b}-83$ a to be an allusion to the burning of Hrothulf's hall in the course of Heoroweard's attack (a conflagration implied by Saxo). Marijane Osborn notes that 'three different occasions for such a fire are available in the traditions, each occurring in a different generation' (Osborn, 'Legends of Lejre, home of kings', p. 252). 
26 Osborn, 'Legends of Lejre, home of kings', p. 253. Klaeber's Beowulf unaccountably omits Heoroweard from the Danish genealogical chart, p. lii.

27 The narrator calls this brief insert a giedd, 'tale, (formal) speech, (enigmatic) discourse'. Its eight lines include two examples of crossalliteration involving royal Danish names (Hiorogar, 2158; Heoroweard, 2161) and a third featuring the gift itself (breostgewadu, 2162). See Scott Gwara, 'Paradigmatic wisdom in the native genre giedd in Old English', Studi medievali, 53 (2012), 783-851.

28 Leo Tolstoy, War and peace, trans. Louise and Aylmer Maude (Ware: Wordsworth Editions, 1993), p. 479.

29 This is the same Ingeld (Hinieldus) named in the 'pagan song' to which the Anglo-Saxon poet and scholar Alcuin objected in his much-cited letter of December 796. (Epistola 81 in W. Wattenbach and Ernst Dümmler [eds], Monumenta Alcuiniana, Bibliotheca rerum Germanicarum [Berlin: Weidmann, 1873; repr. 1964], VI, 357). See Mary Garrison, 'Quid Hinieldus cum Christo?', in Katherine O'Brien O'Keeffe and Andy Orchard (eds), Latin learning and English lore: studies in Anglo-Saxon literature for Michael Lapidge, 2 vols (Toronto: University of Toronto Press, 2005), vol. 1, pp. 237-59. On the Old Norse side, see Russell Poole, 'Some southern perspectives on Starcatherus', Viking and medieval Scandinavia, 2 (2006), 141-66.

30 The poet's artful alliteration in this passage was noted in Orchard, $A$ critical companion to Beowulf, pp. 241-2.

31 David Cronenberg and C. E. Pogue, The fly, directed by David Cronenberg, 20th Century Fox, 1986.

32 'Hropwulf ond Hroðgar heoldon longest/ sibbe ætsomne suhtorfædran, / sippan hy forwræcon Wicinga cynn / ond Ingeldes ord forbigdan, / forheowan æt Heorote Heaðobeardna prym' (Widsith, lines 45-9). Cf. Shakespeare's Pistol garbling Christopher Marlowe's 'holla, ye pampered jades of Asia' as 'And hollow pampered jades of Asia'.

33 The compound here rendered 'chief kinsman' is plural in the manuscripts; the translation 'Randvér's chief kinsmen', referring to the dynasty of the Goths, would be just as ominous. Finnur Jónsson (ed.), Den norsk-islandske skjaldedigtning, 4 vols (Copenhagen: Gyldendal, 1908-15), the standard edition of skaldic poetry for the past century, is being replaced by a new edition of the corpus in nine volumes. For Bragi's stanzas edited by Margaret Clunies Ross, see now Kari Ellen Gade (ed.), Poetry from Treatises on Poetics, Part 1, Skaldic Poetry of the Scandinavian Middle Ages 3 (Turnhout: Brepols, 2017), pp. 31-3, $36-8$.

34 Seamus Heaney, 'Whatever you say say nothing', North: poems (New York: Farrar, Straus, and Giroux, 1975).

35 On the humorous potential of litotes in Beowulf, see Frederick Bracher, 'Understatement in Old English poetry', PMLA, 52 (1937), 915-34. 
See also Roberta Frank, 'The incomparable wryness of Old English poetry', in John Walmsley (ed.), Inside Old English: essays in honour of Bruce Mitchell (Oxford: Blackwell, 2006), pp. 59-73; and most recently, Stephen Graham, "“So what did the Danes feel?” Emotion and litotes in Old English poetry', in Alice Jorgensen, Frances McCormack, and Jonathan Wilcox (eds), Anglo-Saxon emotions: reading the heart in Old English language, literature and culture (Farnham: Ashgate, 2015), pp. 75-90, and bibliography therein.

36 Murray Gell-Mann, The quark and the jaguar: adventures in the simple and the complex (New York: W. H. Freeman, 1994), p. 26.

37 Peter Ackroyd, Albion: the origins of the English imagination (London: Chatto and Windus, 2002), p. 45.

38 Thesis 5 of Walter Benjamin's 1940 Theses on the philosophy of history, ed. Hannah Arendt, trans. Harry Zohn, in Benjamin, Illuminations: essays and reflections (New York: Schocken Books, 1969), p. 255.

39 A black-garbed professor provides similar guidance on Scylding legends in the cartoon series by Claus Deleuran, Illustreret Danmarkshistorie for folket (Copenhagen: Ekstra Bladets Forlag, 1992), vol. 5. Hrothgar's lengthy memento mori advice to Beowulf is comparable to the similar reminders directed from time to time to a general in a Roman triumph - if such a tradition had existed before Tertullian publicized it; see Mary Beard, The Roman triumph (Cambridge, MA: Harvard University Press, 2007), pp. 85-92.

40 Klaeber's Beowulf, p. clxxxviii; Gillian R. Overing, 'Beowulf: a poem in our time', in Clare A. Lees (ed.), The Cambridge history of early medieval English literature (Cambridge: Cambridge University Press, 2013), pp. 309-31, at 309.

41 Nicholas Howe, 'Historicist approaches', in Katherine O'Brien O'Keeffe (ed.), Reading Old English texts (Cambridge: Cambridge University Press, 1997), pp. 79-100, at 80.

42 J. R. R. Tolkien, 'Beowulf: the monsters and the critics', Sir Israel Gollancz Memorial Lecture, Proceedings of the British Academy, 22 (1936), 245-95.

43 J. R. R. Tolkien, Beowulf: a translation and commentary, ed. Christopher Tolkien (Boston: Houghton Mifflin Harcourt, 2014).

44 Joan Acocella, 'Slaying monsters: Tolkien's Beowulf', The New Yorker, 2 June 2014, pp. 70-6, at 76. 